\title{
A COMPARATIVE NEXUS OF IMPACT ASSESSMENT OF FILLING STATION CONSTRUCTION PROJECTS ON ENVIRONMENTAL SUSTAINABILITY IN OWERRI, IMO STATE: AN EMPIRICAL PERSPECTIVE
}

\author{
Joy Okwuchi Chizitere Oguzie ${ }^{1}$, Peter Paul Chiemezie Njoku², Ulari Sylvia Onwuka ${ }^{3}$ \\ ${ }^{1,3}$ Department of Project Management Technology, Federal University of Nigeria, Owerri, \\ Nigeria \\ ${ }^{2}$ Chartered Institute of Project Management, The Saints Innovative Solutions, Nigeria
}

\begin{abstract}
The discovery and use of crude oil and its refined products have evidently had positive effects on the economy but one can't turn a blind eye to the many negative effects it has had and is still having on the environment. Prominent amongst them is the hazardous effects filling stations who are involved in the sale of oil products as the downstream sector have on the environment coupled with the fact that most filling stations do not comply with the reports of Environmental Impact Assessment carried out sequel to their construction. As such, this study sought the significance of EIA exercise in filling stations construction and the extent to which their activities affect the environment in other to ascertain how sustainable the filling stations are. The study which is descriptive survey has a sample size of 110 respondents. Furthermore, the data were analyzed using descriptive statistics and for the hypotheses, using t-test and correlations to ascertain relationships. It was found that the significance/importance of carrying out an EIA exercise is non-negotiable. Further analysis also showed that the filling stations do not go through with what is contained in the EIA reports, as their operations are not also done in accordance with best practices as they release a lot of pollutants to the environment which aids in rapid degradation of the environment. All these prove beyond doubt that filling station construction projects in Owerri, Imo state are not on a sustainable path and as such it is recommended that all stakeholders such as Government regulatory agencies which include the Department of Petroleum Resources, Filling station owners/workers and even personnel in the Construction sector should join hands in ensuring that filling stations are properly planned, constructed and that their operations are environmentally friendly. The Federal Ministry of Environment (FME), Environmental activists, Civil Societies, etc. should also embark on a massive orientation as a large part of the populace do not know what EIA is all about.
\end{abstract}

Key words: environmental impact assessment, sustainability, filling station projects.

\section{INTRODUCTION}

Degradation of the environment is one of the ten threats officially cautioned by the United Nations High-level Panel on Threats, Challenges and Change. This degradation has resulted to the inability of the earth to meet its social and ecological needs and objectives. The reason for this degradation is not self-caused but the resultant effect of the actions of man in his quest to exploit the resources of the earth. The earth being filled with many resources were sought and harnessed by man which gave those that found it economic empowerment. This exploitation started to emerge in an industrial scale in the $19^{\text {th }}$ century as the extraction and processing of raw materials (such as in mining, steam power, and machinery) developed much further than it had in pre-industrial era. This continual depletion no doubt became the subject of great concern to many governments and groups as they began to consider the future of man (with his creations) and the future of the earth. This gave birth to so many terms and terminologies of which "sustainability or sustainable development" is one of them. The United Nations (an apex world body) took the bold step and set up a commission (World Commission on Environment and Development) also known as the Brundtland Commission which defined sustainable 
development as that which "meets the needs of the present without compromising the ability of future generations to meet their own needs." Ever since the publication of the report, great attention has been paid by many governments and organizations to the subject - sustainable development. Many tools and frameworks have been re-enforced while some new ones were developed to ensure its implementation hence confirming indeed that man really wants to save the earth.

Environmental Impact Assessment (EIA) which was first introduced in the United States in 1970 was also identified by the Brundtland commission as a strategic tool that should be employed by all countries to assess the potential environmental impacts of developmental projects. This Environmental Impact Assessment will further provide/suggest ways of mitigating these negative effects of such developmental projects on the environment. When the effects are too severe and might not be controlled, the project's plan might not be implemented at all. Furthermore, with the discovery of crude oil and the fast growing population in Nigeria coupled with the growth in economic activities, many people in the quest to live comfortable and have ease of movement now own their own personal vehicles. These have resulted to the continual increase in the number of vehicles in the country and the increase in the demand for petroleum products as it is the source of energy for all these machines. Also the number of filling stations continually increases as entrepreneurs seek to mitigate the supply gap thereby generating some revenue. Amidst the increase in revenue generated by these ventures, our environment no doubt have continually been degraded as these filling stations pose great treat to our environment especially when they are not checkmated both at their construction phase and operational phase.

With incidents of fire outbreaks in filling stations, destructive effect on the environment and inadequate location of many filling stations (sited close to residential buildings) which is against the regulation of Department of Petroleum Resources (DPR) which is the body responsible for the approval for location of a filling station in the country, abandonment of many filling stations, incorporation of more services in filling stations against their original design, etc. Against all these, one needs to analyze the role of environmental impact assessment and the level of compliance amongst filling station operators so as to ensure protection and preservation of the environment (Mshelia, John, \& Emmanuel, 2015). The primary aim of this project is to evaluate how the application of EIA can improve the quality of filling station construction projects To identify the extent to which sustainability of the environment can be attained with the current filling stations construction and operations trend.

\section{LITERATURE REVIEW}

Sustainability (from 'sustain' and 'ability') is the process of change, in which the exploitation of resources, the direction of investments, the orientation of technological development and institutional change are all in harmony and enhance both current and future potential to meet human needs and aspirations (Michael, et al., 2016).

Research has shown that the issue of sustainability has become a serious challenge all over the world especially after the World War II as many of man's actions in trying meet his needs has caused great devastation to his environment.

\section{Conceptual pillars of Sustainability/ Sustainable development}

Khan (2005) stated that the paradigm of 'sustainable development' as described in Agenda 21, actually rests on three conceptual pillars. These pillars include 'economic sustainability', 'social sustainability', and 'environmental sustainability'

Economic sustainability, by means of growth, development, and productivity, has guided and shaped conventional development science in the past. The belief that economic growth will 'trickle down' to the poor, market allocation of resources, sustained levels of growth and consumption and an assumption that natural resources are unlimited have been its hallmarks. 'Sustainable development' goes beyond development's concern with monetary capital to also include natural, social and human capital. Economic growth and 
consumption which depletes these is unadvisable and steps should be taken to discourage it.

Social sustainability spreads across notions of equity, participation, sharing, empowerment, accessibility, cultural identity, and institutional stability. It seeks to ensure that the environment is preserved through economic growth and the alleviation of poverty.

Environmental sustainability includes ecosystem integrity, carrying capacity and biodiversity. It seeks natural capital being maintained as a source of economic inputs and as a sink for wastes. Resources must not be harvested faster than they can be regenerated. Wastes must be emitted only as fast as they can be assimilated by the environment (Khan, 2005)
The paradigm of sustainable development in Agenda 21 as detailed by Khan (2005).

\section{Element Criteria}

Social Sustainability

- Equity

- Empowerment

- Accessibility

- Participation

- Sharing

- Cultural Identity

- Institutional Stability

Economic Sustainability

- Growth

- Development

- Productivity

- Trickle Down

Environmental Sustainability

- Eco-System Integrity

- Carrying Capacity

- Biodiversity

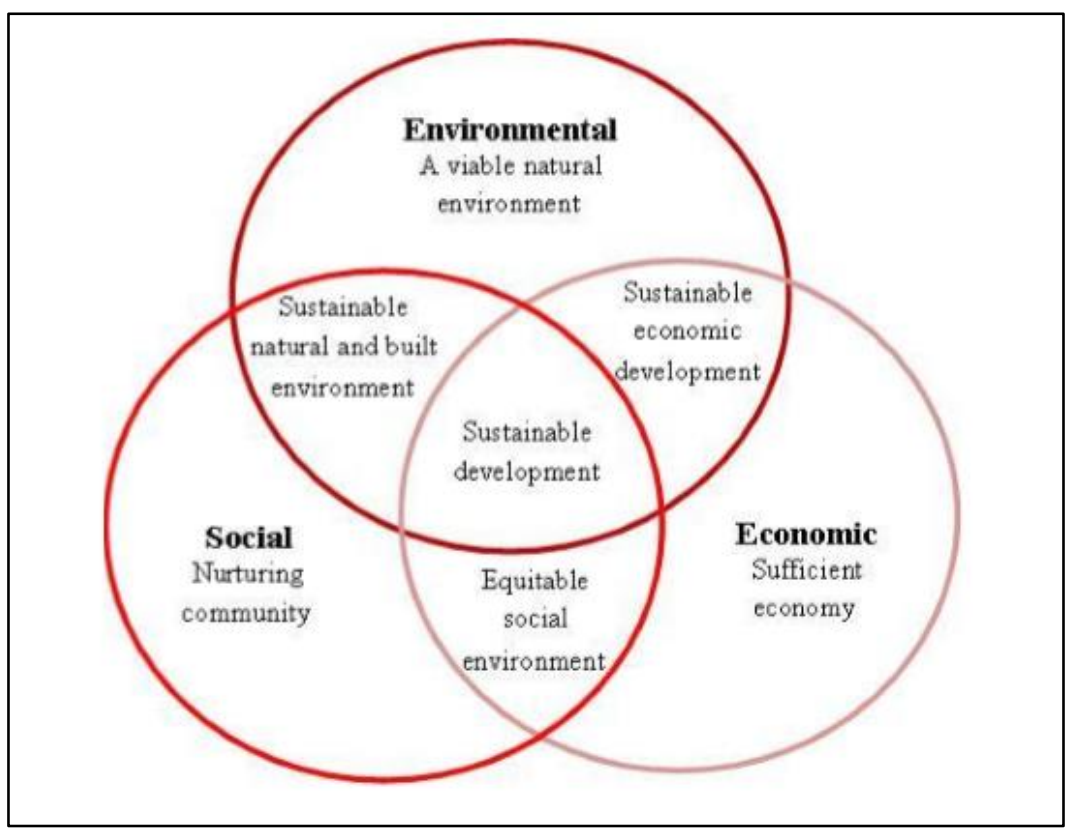

Figure 1. Fundamentals of Sustainable Development (United Nations Conference on Environment and Development, 1992)

\section{EIA IN NIGERIA}

Due to the illegal dumping of toxic wastes in Koko, which is in the former Bendel State in 1987, the Nigerian Government promulgated the Harmful Wastes Decree which served as the legal framework for the effective control of the disposal of toxic and hazardous waste into any environment within the borders of Nigeria. This was immediately followed up with the creation of a regulatory body, the Federal Environmental Protection Agency (FEPA) in 1988. FEPA was charged with the overall responsibility of ensuring that the Nigerian environment is well protected and developed. To ensure its full implementation a National Policy on the Environment was developed. This became the main working document for the preservation and protection of the Nigerian environment. Also, states and local 
government councils were also encouraged to establish their own environmental regulatory bodies for the purpose of maintaining good environmental quality as it applies to their particular terrain (Echefu, \& Akpofure, 2007).

The EIA Decree No. 86 of 1992 was an additional document with the same aim of protecting the Nigerian environment. Its major aim was regulating the industrialization process with due regard to the environment. By this Decree, no industrial plan/development/activity falling under the FEPA's mandatory list could be carried out without prior consideration of the environmental consequences of such a proposed action, in the form of an environmental impact assessment. The EIA process in Nigeria is not a one-way process that results in the preparation of a report that contains the effects of the project and associated mitigation measures. It also deals with monitoring the constructional and operational phases, and acting on the results of such monitoring up until final abandonment/closure (Yusuf, Agarry, \& Durojaiye, 2008). The post closure care is also an integral part of the EIA process.

The EIA procedure in Nigeria according to the Federal Ministry of Environment, Housing and Urban Development (FMEH \& UD) EIA procedure, involves the following steps:

1. The submission of project proposal to the Federal Ministry of Environment for screening to determine the need or otherwise for EIA.

2. The vetting of Terms of Reference (TOR) for the EIA studies to ensure that only significant issues (impacts) are studied in the EIA. A site verification exercise may be required to aid the process.

3. Submission of draft EIA report for review.

4. Review of draft EIA report.

5. Submission of final EIA report, which addresses all the issues raised from EIA exercise.

6. Decision-making by the Federal Ministry of Environment's technical committee and the Honorable Minister.
7. Certification (issuance of Environmental Impact Statement (EIS) and certification).

8. Mitigation and compliance monitoring to ensure compliance with all stipulated mitigation measures and project specifications in the project's EIA report.

The EIA process cuts across the various stages a project undergoes from proposal to approval for implementation, resulting in the issuing of an Environmental Impact Statement (EIS) and certificate (Echefu, \& Akpofure, 2007). The evaluation is completed with a review of the report; there are different forms of review depending on factors such as the nature, scope, anticipated impacts, etc.

\section{EFFECTS OF FILLING STATION CONSTRUCTION AND OPERATION ON THE ENVIRONMENT}

Filling stations represent a business activity branch that works primarily with the retail sale of fuel (fossil fuel). These endeavors store various types of fuel tanks that in most cases are underground, and they also possess a set of lines and pumps that are part of the storage system and commercialization of products. Because of the storages and subsequent activities that take place there, there is high possibility of degrading the environment.

The contamination of the soil and underground water is one of the major environmental impacts caused by the activities of filling stations, since this is related to health problems, environmental damage and adverse social impacts. There are several known causes and sources of groundwater contamination. However, one of the most hazardous is contamination through leaks in underground storage tanks of fuel, the severity of which increases due to the characteristics of the fuels being rich in toxic substances of a mutagenic and carcinogenic character, and to the great likelihood of movement in the soil, and the fact that a leak is not always detected immediately. Over time these tanks may leak due to corrosion, cracks, defective piping, and spills during refilling and maintenance activities. Petroleum and other fuels pollution from leaking underground storage tanks leaches into the surrounding soil and groundwater and can 
contaminate nearby water bodies and ecological systems (Thales, 2015).

Gas stations exist as part of the built environment and are widely located across localities. As a result, they may be surrounded by residential dwellings, businesses, and other buildings such as schools, religious stations, etc. Operation of filling stations may thus create opportunities for a variety of human populations to be exposed to vapors during station tank filling and vehicle refueling. These human populations can be broadly grouped into three groups: populations exposed occupationally as a result of employment in various capacities at the service station; those exposed as customers engaging in vehicle refueling; and those passively exposed either by residing, at- tending school, or working near the refueling station. The rate of exposure of the population to these poisonous gases is influenced by the size and capacity of the refueling station, spatial variation in pollutant concentrations in ambient air, climate, meteorological conditions, time spent at varying locations of the service station, changing on-site activity patterns, physiological characteristics, and the use of vapor recovery and other pollution prevention technologies (Markus, Bernat, Ni, Ana, \& Keeve, 2015).

\section{RESEARCH DESIGN}

In view of the scope the strategy adopted involves the use of descriptive and crosssectional survey. The questionnaires administered consist of multiple-choice question. This is in agreement with Baridam (2001) observation that multiple — choice question are quick and easy for the interview to handle. It is easier to analyze statistically than using the opened question. The populations of study in this study are mainly filling station workers, govt. agencies, construction professionals and this include all those involved in carrying out an assessment of the Environmental Impact a filling station project would have on the environment.

Another very important component of the population under study, is the locals i.e. those dwelling in the area where the filling station construction project is sited or to be sited. This is because they constitute the living components of the environment and are the ones directly affected by the activities of the filling station be it positive or negative. The sample size of this research is 110 respondents as a total of 160 questionnaires were distributed, 140 were retrieved and 30 out of 140 wrongly/not filled. This sample study are made of construction professionals of filling station construction projects (especially those concerned with/in the EIA process), filling station workers, govt. agencies together with the locals as earlier stated, and the procedure employed is probabilistic sampling which gives every respondent equal opportunity to express opinion and ensures reliability of information obtained and randomization sampling technique which was used in obtaining information from sample, by removing all elements of bias from a particular section of people. The instrument used in data collection and measurement are questionnaire, interview and participant observation method. The data were analyzed using Simple percentage and relevant descriptive statistics. However, for the hypothesis, Pearson correlation method and T-test were used to analyze the hypothesis.

\section{DATA ANALYSIS \\ Respondents in their Strata}

Table 1: Relationship between EIA and filling station (Const. Professionals/EIA Experts, $\mathrm{n}=67$ )

\begin{tabular}{|l|c|c|}
\hline $\begin{array}{l}\text { Respondents } \\
\text { Category }\end{array}$ & Frequency & Percentage (\%) \\
\hline $\begin{array}{l}\text { Construction } \\
\text { Professionals/EIA } \\
\text { Experts/Agencies }\end{array}$ & 67 & 61.0 \\
\hline $\begin{array}{l}\text { Community } \\
\text { Members/Filling Station } \\
\text { Workers }\end{array}$ & 43 & 39.0 \\
\hline Total & & 100 \\
\hline
\end{tabular}




\begin{tabular}{|c|c|c|c|}
\hline & Item & Frequency & Percentage (\%) \\
\hline \multirow[t]{2}{*}{1} & $\begin{array}{l}\text { Was EIA carried out for } \\
\text { the filling station }\end{array}$ & $\begin{array}{l}\text { Yes } \\
\text { No } \\
\text { Undecided }\end{array}$ & $\begin{array}{c}73.13 \\
2.89 \\
23.88\end{array}$ \\
\hline & Total & 67 & 100 \\
\hline \multirow[t]{2}{*}{2} & $\begin{array}{l}\text { Stage at which EIA was } \\
\text { carried out }\end{array}$ & $\begin{array}{l}\text { Before Construction } \\
\text { During Construction } \\
\text { After Construction }\end{array}$ & $\begin{array}{l}59.18 \\
16.33 \\
24.49\end{array}$ \\
\hline & Total & 49 & 100 \\
\hline 3 & Was the cost of EIA high & $\begin{array}{l}\text { Yes } \\
\text { No } \\
\text { Undecided }\end{array}$ & $\begin{array}{l}51.02 \\
30.61 \\
18.37\end{array}$ \\
\hline & Total & 49 & 100 \\
\hline 4 & $\begin{array}{l}\text { Were there changes } \\
\text { made in the project } \\
\text { design due to EIA }\end{array}$ & $\begin{array}{l}\text { Yes } \\
\text { No } \\
\text { Undecided } \\
\end{array}$ & $\begin{array}{l}40.82 \\
42.86 \\
16.33 \\
\end{array}$ \\
\hline & Total & 49 & 100 \\
\hline 5 & $\begin{array}{l}\text { Did the changes made } \\
\text { result to increase in the } \\
\text { total cost of the project }\end{array}$ & $\begin{array}{l}\text { Yes } \\
\text { No } \\
\text { Undecided } \\
\end{array}$ & $\begin{array}{l}50 \\
35 \\
15 \\
\end{array}$ \\
\hline & Total & 20 & 100 \\
\hline
\end{tabular}

The table above depicts the strata of respondents and their percentages, however, some selected members of both stratum were grafted totaling 54 to answer research question three.

\section{Research Question One}

The table above shows the relationship between EIA and filling station construction. The result reflects the opinion of respondent in this category, there are 67 respondents and thus some questions has total different from 67 due to question type especially following preceding question. The results shows that $73.13 \%$ reported that EIA was carried out in their filling station, while $2.89 \%$ reported that it was not carried out in their filling station, while the rest was undecided.

However, some of the responses were based on the responses in the previous item/s or item/s before (for example, if yes, we used the total of those that answered yes to answer the following question that require only thereby making the total to vary Majority also reported that EIA was carried out before the construction stage of the project. High cost of EIA was also discovered as $51.02 \%$ reported that the cost of carrying out the EIA was high. The result also shows that $67.35 \%$ of the EIA was carried out by the government agency. The high cost of EIA can be linked back to the government agency. This shows that the government agency in charge charges high amount of money for the EIA. This may discourage people from carrying out EIA. The study also reveals that there is a high level of monitoring of the activities of the filling station by the government agencies. These visits were meant to ensure that they comply with set rules guiding the industry and to ensure safety of lives. 


\section{Research Question Two}

Table 2: Effects of Filling Station on the environment (Community Members/Filling Station Workers, $n=43$ )

\begin{tabular}{|c|c|c|c|c|c|c|c|c|c|c|c|c|c|}
\hline & & SA & $\mathrm{F}$ & $\mathbf{A}$ & $\mathrm{F}$ & $\mathbf{N}$ & $\mathrm{F}$ & D & $\mathrm{F}$ & SD & $\mathrm{F}$ & $\mathbf{T}$ & $\mathrm{F}$ \\
\hline 1 & $\begin{array}{l}\text { Noise form } \\
\text { the } \\
\text { generating set } \\
\text { of the filling } \\
\text { station } \\
\text { disturbs the } \\
\text { public }\end{array}$ & 2 & 4.65 & 12 & 27.91 & 11 & 25.58 & 16 & 37.21 & 2 & 4.65 & 43 & 100 \\
\hline 2 & $\begin{array}{l}\text { There is } \\
\text { usually traffic } \\
\text { congestion } \\
\text { during } \\
\text { operating } \\
\text { hours of the } \\
\text { filling station }\end{array}$ & 0 & 0 & 4 & 9.52 & 14 & 33.33 & 23 & 54.76 & 1 & 2.38 & 43 & 100 \\
\hline 3 & $\begin{array}{l}\text { There have } \\
\text { been cases of } \\
\text { air pollution } \\
\text { due to the } \\
\text { operations of } \\
\text { the filling } \\
\text { station }\end{array}$ & 7 & 16.67 & 26 & 61.90 & 3 & 7.14 & 5 & 11.90 & 1 & 2.38 & 43 & 100 \\
\hline 4 & $\begin{array}{l}\text { The wastes } \\
\text { generated by } \\
\text { the filling } \\
\text { station is not } \\
\text { managed or } \\
\text { disposed } \\
\text { properly }\end{array}$ & 3 & 6.98 & 20 & 46.51 & 11 & 25.58 & 8 & 18.60 & 1 & 2.33 & 43 & 100 \\
\hline 5 & $\begin{array}{l}\text { Any case of } \\
\text { fire outbreak } \\
\text { in the filling } \\
\text { station will } \\
\text { greatly affect } \\
\text { nearby } \\
\text { residents }\end{array}$ & 23 & 54.76 & 18 & 41.86 & 0 & 0 & 0 & 0 & 1 & 2.38 & 43 & 100 \\
\hline 6 & $\begin{array}{l}\text { There is no } \\
\text { adequate } \\
\text { firefighting } \\
\text { equipment in } \\
\text { the filling } \\
\text { station }\end{array}$ & 2 & 4.76 & 14 & 33.33 & 19 & 45.24 & 4 & 9.52 & 3 & 7.14 & 43 & 100 \\
\hline
\end{tabular}

Source: Field data, 2019

NB: SA = Strongly agree, A=Agree, $N=$ Neutral, $D=$ Disagree, $S D=$ =Strongly Disagree

The table shows the impacts of filling station on the environment as identified by the community members. The results show a high level of negative impact of filling station construction and operations on the environment.

\section{Research Question Three}


Table 3: The Current Filling Station Construction and Operation Trend (Selected Respondents from stratum 1 and $2=54$ )

\begin{tabular}{|c|c|c|c|c|}
\hline \multirow[b]{2}{*}{1} & \multirow{2}{*}{$\begin{array}{l}\text { Item } \\
\text { Are there safety training for } \\
\text { workers before employment? }\end{array}$} & \multicolumn{2}{|c|}{ Frequency } & \multirow{2}{*}{$\begin{array}{c}\text { Percentage }(\%) \\
83.33 \\
16.67\end{array}$} \\
\hline & & $\begin{array}{l}\text { Yes } \\
\text { No }\end{array}$ & $\begin{array}{c}45 \\
9\end{array}$ & \\
\hline & Total & & 54 & 100 \\
\hline 2 & $\begin{array}{l}\text { Are workers given personal } \\
\text { protective equipment? }\end{array}$ & $\begin{array}{l}\text { Yes } \\
\text { No }\end{array}$ & $\begin{array}{l}25 \\
29\end{array}$ & $\begin{array}{l}46.30 \\
53.70\end{array}$ \\
\hline & Total & & 54 & 100 \\
\hline 3 & $\begin{array}{l}\text { Are workers mandated to use the } \\
\text { personal protective equipment? }\end{array}$ & $\begin{array}{l}\text { Yes } \\
\text { No }\end{array}$ & $\begin{array}{l}24 \\
30\end{array}$ & $\begin{array}{l}41.18 \\
58.82\end{array}$ \\
\hline & Total & & 54 & 100 \\
\hline 4 & Are there firefighting equipment? & $\begin{array}{l}\text { Yes } \\
\text { No }\end{array}$ & $\begin{array}{r}53 \\
1\end{array}$ & $\begin{array}{c}98.18 \\
1.82\end{array}$ \\
\hline- & Total & & 54 & 100 \\
\hline 5 & $\begin{array}{l}\text { Is there fire detection system } \\
\text { installed? }\end{array}$ & $\begin{array}{l}\text { Yes } \\
\text { No }\end{array}$ & $\begin{array}{l}21 \\
33 \\
\end{array}$ & $\begin{array}{l}38.89 \\
61.11 \\
\end{array}$ \\
\hline & Total & & 54 & 100 \\
\hline 6 & $\begin{array}{l}\text { How often the fire detection } \\
\text { system is maintained? }\end{array}$ & $\begin{array}{l}\text { 1-6 Month } \\
\text { 6-12 Month } \\
\text { Above } 2 \text { Years }\end{array}$ & $\begin{array}{r}14 \\
17 \\
2\end{array}$ & $\begin{array}{c}45.71 \\
48.57 \\
5.72\end{array}$ \\
\hline & Total & & 33 & 100 \\
\hline 7 & $\begin{array}{l}\text { Have there been underground tank } \\
\text { leakages in the station? }\end{array}$ & $\begin{array}{l}\text { Yes } \\
\text { No }\end{array}$ & $\begin{array}{l}10 \\
44\end{array}$ & $\begin{array}{l}17.31 \\
82.69\end{array}$ \\
\hline & Total & & 54 & 100 \\
\hline 8 & $\begin{array}{l}\text { Is there a mechanism to detect } \\
\text { underground tank leakage? }\end{array}$ & $\begin{array}{l}\text { Yes } \\
\text { No }\end{array}$ & $\begin{array}{l}24 \\
30\end{array}$ & $\begin{array}{l}44.23 \\
55.77\end{array}$ \\
\hline & Total & & 54 & 100 \\
\hline 9 & $\begin{array}{l}\text { How often the tanks are checked } \\
\text { for leakage? }\end{array}$ & $\begin{array}{l}\text { 1-6 Months } \\
\text { 6-12 Months } \\
\text { Above } 2 \text { Years }\end{array}$ & $\begin{array}{r}23 \\
27 \\
4 \\
\end{array}$ & $\begin{array}{c}42.59 \\
50.00 \\
7.41\end{array}$ \\
\hline & Total & & 54 & 100 \\
\hline 10 & Are runoff water treated? & $\begin{array}{l}\text { Yes } \\
\text { No }\end{array}$ & $\begin{array}{ll}13 \\
41 \\
\end{array}$ & $\begin{array}{c}24.10 \\
75.9 \\
\end{array}$ \\
\hline & Total & & 54 & 100 \\
\hline 11 & $\begin{array}{l}\text { How waste from the filling station } \\
\text { disposed? }\end{array}$ & $\begin{array}{l}\text { Thrown to public drainage } \\
\text { Burning } \\
\text { Burying } \\
\text { Thrown into the bush }\end{array}$ & $\begin{array}{r}10 \\
15 \\
4 \\
25\end{array}$ & $\begin{array}{c}18.51 \\
27.77 \\
7.4 \\
46.29\end{array}$ \\
\hline & Total & & 54 & 100 \\
\hline 12 & $\begin{array}{l}\text { Any proactive way adopted to } \\
\text { reduce waste? }\end{array}$ & $\begin{array}{l}\text { Yes } \\
\text { No }\end{array}$ & $\begin{array}{l}30 \\
24 \\
\end{array}$ & $\begin{array}{l}53.85 \\
46.15 \\
\end{array}$ \\
\hline & Total & & 54 & 100 \\
\hline
\end{tabular}

Source: Field data, 2019.

The table above shows the current operational and construction trends amongst the filling stations. A critical look and study of the table shows that $55.77 \%$ of the filling stations do not have a mechanism to detect underground tank leakage.
$61.11 \%$ do not have a fire detection system. $49.02 \%$ of the wastes generated are thrown into the bush. All these and much more shows that we are not on a sustainable path. 


\section{Test of Hypothesis}

Hypothesis One
$\mathrm{H}_{01}$ : There is no significant relationship between EIA exercise and sustainability of filling station construction projects.

Table 4: Descriptive Statistics for Hypothesis One

\begin{tabular}{|l|l|r|r|}
\hline & Mean & Std. Deviation & $\mathrm{N}$ \\
\hline EIA Exercise & 20.7182 & 2.25499 & 110 \\
\hline $\begin{array}{l}\text { Sustainability of filling stations } \\
\text { construction projects }\end{array}$ & 20.7909 & 1.79753 & 110 \\
\hline
\end{tabular}

Table 5: Correlations Statistics for Hypothesis One

\begin{tabular}{|l|l|r|r|}
\hline \multicolumn{2}{|c|}{} & EIA Exercise & \multicolumn{2}{|c|}{$\begin{array}{c}\text { Sustainability Of Filling Stations } \\
\text { Construction Projects }\end{array}$} \\
\hline \multirow{3}{*}{ EIA Exercise } & Pearson Correlation & 1 & .882 \\
\cline { 2 - 4 } & Sig. (2-tailed) & & .000 \\
\cline { 2 - 4 } & $\mathrm{N}$ & 110 & 110 \\
\hline \multirow{2}{*}{$\begin{array}{l}\text { Sustainability of Filling } \\
\text { Stations Construction } \\
\text { Projects }\end{array}$} & Pearson Correlation & .882 & 1 \\
\cline { 2 - 5 } & Sig. (2-tailed) & .000 & 110 \\
\cline { 2 - 5 } & $\mathrm{N}$ & 110 & \\
\hline
\end{tabular}

From the table above, the Pearson correlation shows a value of 0.882 which represents a strong positive relationship; and as such from the correlation decision rule, a rho (r) value above \pm 0.5 signifies a strong relationship either in the negative or positive, and from \pm 0.7 clearly depicts a very strong relationship. Since value in the table above is 0.882 , we conclude that there is a high level of relationship between EIA exercise and sustainability of filling stations construction projects. To buttress the decision, the sig. value is 0.000 , which is lower than the p-text value of 0.05 level of significance; therefore we reject the null hypothesis and accept the alternative which says that there is a significant relationship between EIA exercise and sustainability of filling station construction projects.

\section{Hypothesis Two}

$\mathrm{H}_{1}$ : The awareness of EIA exercise by the local community is not significant as regards the current demands of stakeholder commitment.

Table 6: Correlations Statistics for Hypothesis Two

\begin{tabular}{|c|c|c|c|}
\hline & & $\begin{array}{c}\text { Awareness Of EIA } \\
\text { Exercise By Local } \\
\text { Community } \\
\end{array}$ & $\begin{array}{c}\text { Current Demands Of } \\
\text { Stakeholders } \\
\text { Commitment } \\
\end{array}$ \\
\hline \multirow{3}{*}{$\begin{array}{l}\text { Awareness of EIA Exercise } \\
\text { by Local Community }\end{array}$} & Pearson Correlation & 1 & -.132 \\
\hline & Sig. (2-tailed) & & .170 \\
\hline & $\mathrm{N}$ & 110 & 110 \\
\hline \multirow{3}{*}{$\begin{array}{l}\text { Current Demands of } \\
\text { Stakeholders Commitment }\end{array}$} & Pearson Correlation & -.132 & 1 \\
\hline & Sig. (2-tailed) & .170 & \\
\hline & $\mathrm{N}$ & 110 & 110 \\
\hline
\end{tabular}

From the table above, the Pearson correlation shows a value of -0.132 which represents a strong negative relationship; and as such from the correlation decision rule, a rho (r) value of $\pm 0.1- \pm 0.49$ signifies a weak relationship either in the negative or positive. Since value 
in the table above is -0.132 , we conclude that there is a weak relationship between awareness of EIA exercise by the local community and current demands of stakeholder commitment. To buttress the decision, the sig. value is 0.1700 , which is lower than the p-text value of 0.05 level of significance; therefore we accept the null hypothesis that the awareness of EIA exercise by the local community is not significant as regards the current demands of stakeholder commitment.

\section{CONCLUSION}

The study is an Impact Assessment of filling station construction projects on Environmental Sustainability with Owerri as the study area; showing the importance of carrying out an extensive EIA before the commencement of filling station projects. The effects of filling station construction projects on the environment; which doesn't augur well for environmental sustainability is emphasized and the level of awareness/involvement of the local community in EIA exercise was also studied. The study agrees with Aisha and Olatunde (2017) that filling stations do not work with their EIA results especially in the construction phase of the project and during operations, hence we are not on a sustainable path.

\section{RECOMMENDATIONS}

For sustainable filling station construction which would in the long run contribute to environmental sustainability, the follwing recommondations are proposed:

1. The Department of Petroleum Resources need to carry a reevaluation of all filling stations so as to determine their level of compliance with its guidelines for operating a filling station and mete out strict sanctions to those who do not comply with the guidelines. These reevaluations should be carried out yearly.

2. The public need to be sensitised on Environmental Impact Assessment so that they can be involved in the process and ensure that it is carried out for relevant projects in their neighbourhood.
3. The design of filling stations should be made to show how runnoff water will be treated before it is introduced to the public drainage.

4. There should be improvement in the design of underground tanks so as to put in place a system that can detect underground leaks.

5. Filling station operators should consider other alternative sources of energy that are renewable and that generates less noise.

6. Further research should be carried on mitigative measures to be employed in reducing the negative effects of filling station construction projects on the environment.

\section{REFERENCES}

Aisha, P. A., \& Olatunde, F. A. (2017). Application of Sustainable Environmental Design requirements in Filling Stations in Niger State Nigeria. Confluence Journal Of Environmental Studies, 104-116.

Baridam (2001). Resrearch methods in Administrative Sciences; Port Harcourt; Sherbrooke Associates.

Echefu, N., \& Akpofure, E. (2007), "Environmental Impact Assessment in Nigeria: Regulatory Background and Procedural Framework".

Khan, M. A. (2005). Sustainable Development:

The Key Concepts, Issues and Implications. ERP Environment

Markus, H., Bernat, A. M., Ni, J., Ana, M. R., \& Keeve, E. N. (2015). Hydrocarbon Release During Fuel Storage and Transfer at Gas Stations: Environmental and Health Effects. Current Environment Health Report, 412-422.

Michael, H., Liana, W., Potts, R., Aysin, D.-H., Silvia, S.-N., Julie, D., \& Patrick, N. (2016). Environmental Sustainability: A Case of Policy Implementation Failure? $M D P I$.

Mshelia, A., John, A., \& Emmanuel, D. D. (2015). Environmental Effects of Petrol Stations at Close Proximities to Residential Buildings in Maiduguri and Jere, Borno State, Nigeria. Journal of Humanities and Social Science, 1-8. 
Thales, B. D. (2015). Environmental Impacts Management of a Brazilian Gas Station: A Case Study. Global Journal of Researches in Engineering.

United Nations. (1987). Our Common Future. New York: Oxford University Press.

United Nations Conference on Environment and Development. (1992). Agenda 21. Rio de Janeiro, Brazil.
Yusuf, R., Agarry, S., \& Durojaiye, A. O. (2008). Environmental impact challenges in Nigeria. Journal of Environmental Science and Technology. 2. 75-82. 